\title{
IMPACT OF SPORT DANCING ON THE DYNAMICS CHARACTERISTIC OF FOOT MOVEMENT OF COLLEGE STUDENTS
}

\author{
Yi LIU** \\ College of Physical Education, Hubei University, Wuhan 430062, China, email: wushuliuyi@163.com
}

Received: 25.10.2017

Accepted: 24.05.2018

https://doi.org/10.24264/Ifj.18.2.5

IMPACT OF SPORT DANCING ON THE DYNAMICS CHARACTERISTIC OF FOOT MOVEMENT OF COLLEGE STUDENTS

ABSTRACT. With the merits of improving physical quality, body shaping and physical aesthetics, sport dancing is more and more popular among college students. The gestural movement of sport dancing is mainly realized through the reaction of feet after contacting the ground, so it is necessary to scientifically analyze the influence of sport dancing on the dynamics characteristic of foot movement of college students. In this paper, the effect of sport dancing on the insole pressure intensity and gait characteristics of college students is studied by means of experimental test. First, relevant concepts were elaborated. In the experimental test, the foot pressure test system was adopted. And then analysis was made after the comparison between the experimental group and the control group. Finally, analysis and discussion of the experimental results were carried out. This paper is of great significance for evaluating the impact of sport dancing on the healthy development of college students' feet and guiding the force condition of the feet in sport dancing.

KEY WORDS: sport dancing, foot pressure test system, gait, insole pressure intensity, experimental test

IMPACTUL DANSULUI SPORTIV ASUPRA CARACTERISTICII DINAMICE A MIȘCĂRII PICIORULUI LA STUDENṬI UNIVERSITARI

REZUMAT. Având merite precum îmbunătățirea calității fizice, a formei corporale și a esteticii fizice, dansul sportiv este din ce în ce mai popular printre studenți. Mișcarea gestuală a dansului sportiv se realizează în principal prin reacția picioarelor după contactul cu solul, așadar este necesar să se analizeze științific influența dansului sportiv asupra caracteristicii dinamice a misccării picioarelor studenților. În această lucrare se studiază efectul dansului sportiv asupra intensității presiunii branțului și caracteristicile de mers ale studenților prin intermediul unui test experimental. În primul rând, au fost elaborate concepte relevante. În cadrul testului experimental a fost adoptat sistemul de testare a presiunii piciorului. Apoi s-a efectuat o analiză în urma comparației dintre grupul experimental și grupul martor. În cele din urmă, s-au analizat și discutat rezultatele experimentale. Această lucrare are o mare importanță pentru evaluarea impactului dansului sportiv asupra dezvoltării sănătoase a picioarelor studenților și pentru direcționarea forței picioarelor în dansul sportiv.

CUVINTE CHEIE: dans sportiv, sistem de testare a presiunii piciorului, mers, intensitatea presiunii branțului, test experimental

L'IMPACT DE LA DANSE SPORTIVE SUR LA CARACTÉRISTIQUE DYNAMIQUE DU MOUVEMENT DU PIED AUX ÉTUDIANTS UNIVERSITAIRES RÉSUMÉ. Ayant des mérites tels que l'amélioration de la qualité physique, la forme du corps et l'esthétique physique, la danse sportive est de plus en plus populaire parmi les étudiants. Le mouvement gestuel de la danse sportive est principalement réalisé par la réaction des pieds après le contact avec le sol, il est donc nécessaire d'analyser scientifiquement l'influence de la danse sportive sur la caractéristique dynamique du mouvement des pieds des élèves. Dans cet article, on étudie l'effet de la danse sportive sur l'intensité de la pression de la semelle intérieure et les caractéristiques de la marche des étudiants par un test expérimental. Tout d'abord, des concepts pertinents ont été développés. Dans le test expérimental, le système de test de pression du pied a été adopté. Une analyse a été faite suite à la comparaison entre le groupe expérimental et le groupe témoin. Finalement, les résultats expérimentaux ont été analysés et discutés. Ce travail est d'une grande importance pour l'évaluation de l'impact de la danse sportive sur le développement sain des pieds des étudiants et pour la direction de la force de la jambe dans la danse sportive.

MOTS CLÉS: danse sportive, système de test de pression du pied, démarche, intensité de la pression de la semelle intérieure, test expérimental

* Correspondence to: Y. LIU, College of Physical Education, Hubei University, Wuhan 430062, China, wushuliuyi@163.com 


\section{INTRODUCTION}

As a new sports program combining dancing and sports, sport dancing not only exercises the body, but also is of great appreciation value [1]. Currently, Latin dance and modern dance are included in the formal competition items of sports dance. Sport dancing is becoming more and more popular, because it has sport and artistic characteristics at the same time, integrates bodybuilding into physical and mental adjustment and is unrestricted by site, fitness equipment and age.

According to relevant investigation and analysis, sport dancing has a positive effect on the nervous system, cardiopulmonary system, constitution, physical quality, and body shape of humans. The college period is the critical period of physical growth. And the positive influence of sport dancing can improve the self-confidence of college students and exercise their minds. At present, more and more college students choose sport dancing courses in physical education [2].

In dance sport, the dance movements are finished through combining the acting force generated after the feet contact the ground and the body's coordinated control. The joints and parts of the body are exercised through muscle coordination throughout the body. But in the sports dance, the main stress position of the body is the foot. The sport dancing includes such actions as step touch, striding, hop step, etc. The dynamic characteristic of the foot movement of college students are influenced unconsciously in their sport dancing exercises. Combining with the modern foot pressure measurement system, and on the basis of elaborating on the theory of relevant foot characteristics, this paper takes five 2013 college students from the Sports Performance Art Department at a domestic physical culture institute as the test objects of the experimental group, and five sport dancing beginners as the test objects of the control group. The mathematical statistics of the plantar kinetics parameters were carried out when they are walking normally. After analyzing the plantar pressure distribution and gait characteristics, this paper probes into the impact of sport dancing on the dynamics characteristic of foot movement of college students. This paper provides theoretical guidance for promoting the popularization of sports dance.

\section{OVERVIEW OF RELEVANT THEORIES ON THE DYNAMICS OF HUMAN FOOT MOVEMENT}

\section{Foot Bones}

Foot is one of the important organs of human bodies. The bones of foot are composed of 7 tarsals, 5 metatarsals and 14 phalanxes, which constitute a rigid entity [3]. Together with the muscles of the foot, these bones form an important part of human body, which play the role of weight bearing, buffering, absorbing impact, and maintaining body balance. Figure 1 shows the distribution of the foot skeleton.

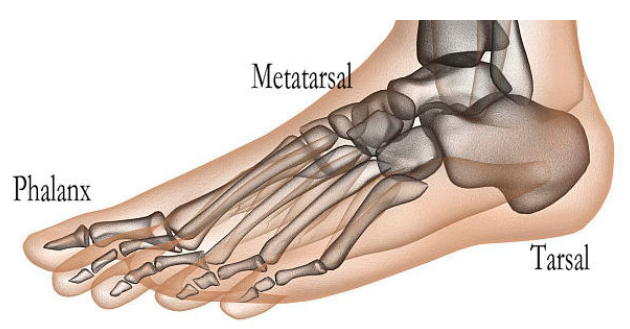

Figure 1. Foot skeleton distribution diagram

As shown in Figure 1, the foot bones and muscles form a flexible and rigid entity. The intensity of pressure between the foot and the ground is 1.5 to 10 times of the body weight in different movements. Therefore, studying the dynamic characteristics of foot movement is a prerequisite to understand and protect the foot and also a guarantee for the healthy development of the foot of college students [4].

\section{Foot Gait Characteristics and Pressure}

\section{Foot Gait}

The posture of a person when he/she walks naturally is called the "gait". It is the external manifestation of the human foot's structure, function and the movement regulating system, and can reflect the function, spirit and the mentality of the human body [5].

Current gait measurement methods include image measurement, measurement of the reaction force of the support force, EMG measurement, etc. The biomechanical study of gait refers to applied research of the test, analysis and evaluation of the function and state of human walking using biomechanical methods and techniques and based on the basic theory of 
human anatomy and physiology [6]. Generally, the cycle, step size, step frequency, and time phase are the key parameters to study the gait. This paper takes gait as a major feature to reflect the dynamics of the foot movement of college students engaged in sports dancing.

\section{Foot Pressure}

Foot pressure is the main research area of foot movement mechanics. Foot pressure is divided into static pressure and dynamic pressure. Static pressure refers to the foot pressure distribution when the foot is standing statically, and the dynamic pressure refers to the situation of the foot pressure distribution changing over time when the body is engaged in different movements [7]. The size of the healthy foot pressure is affected by the weight, age, and daily physical activity. The application research of foot pressure has extended to medical physiotherapy and rehabilitation, sports military training, industrial shoemaking, and so on [8].

According to the sense judgement, the foot heel bears the maximum pressure, which is followed by the metatarsal bones. The toes bear the smallest pressure. With the development of computer technology, and combining with mechanics, geometry and other knowledge, more and more foot measurement technology can accurately measure the foot pressure. The application of these measurement techniques to the study of the foot dynamic characteristics provides a reliable measurement tool for theoretical researches and also provides guarantee for the practical applications [9].

\section{EXPERIMENT DESIGN}

\section{Experiment Object}

Table 1: The basic information of test group and control group

\begin{tabular}{ccccccc}
\hline \multirow{2}{*}{ Item } & Gender & Height & Weight & Shoe size & Training years & Insole size \\
\hline 1 & Female & 160.5 & 41 & 35 & 3 & $35 / 36$ \\
2 & Female & 161.1 & 48.5 & 36 & 4 & $35 / 36$ \\
3 & Female & 163.4 & 49 & 35 & 3 & $35 / 36$ \\
4 & Female & 164 & 46 & 36 & 3 & $35 / 36$ \\
5 & Female & 167 & 63.4 & 37 & 4 & $37 / 38$ \\
\hline 6 & Female & 162 & 58 & 37 & 1 & $37 / 38$ \\
7 & Female & 163 & 45.1 & 37 & 2 & $37 / 38$ \\
8 & Female & 163 & 45.7 & 37 & 1 & $37 / 38$ \\
9 & Female & 162 & 48.1 & 36 & 1 & $37 / 38$ \\
10 & Female & 165 & 47.1 & 37 & 1 & $37 / 38$ \\
\hline
\end{tabular}

This paper takes five girl students from a sports art class at a domestic physical culture institute as the test subjects of the experimental group, and five students without sport dancing basis as the test subjects of the control group [10]. Their basic information is shown in Table 1.

\section{Test Equipment}

In this study, the insole pressure measuring system produced by Medilogic of Germany was adopted. The insole has 64 FSR pressure sensors. The pressure range tested was $0.5^{\sim} 65 \mathrm{~N} / \mathrm{cm}^{2}$ and the sampling frequency reached $350 \mathrm{~Hz}$ [11]. 


\section{Test Process Design}

The test is arranged in the school gymnasium. During the test, 10 students in the test group and the control group were asked to walk at a normal speed and with normal postures and ensure that the insoles match their shoe sizes and that the insoles were not folded to guarantee the accuracy of the data. Specific test procedures are as follows:

(1) Collect the basic information of testees based on Table 1

(2) Warm-up of the testees and learn the attentions

(3) Instrument installation and debugging

(4) Test data recording and filing

(5) Instrument removal and checking the insole condition

Observe the students' situation during the test and ensure that the instrument is in normal working condition and operating condition. Figure 2 shows the situation of the female testees with the instrument put on their body.

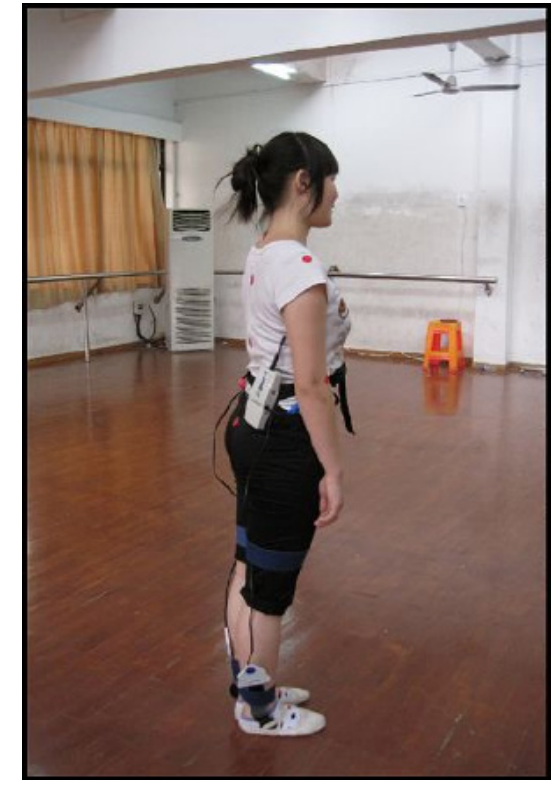

Figure 2 . The test situation of the student with insole pressure test device

\section{Data Statistics and Test Indicators}

\section{Data statistical Method}

SPSS11.5 statistical analysis package is adopted for mathematical statistics and $T$ detection was applied to complete the analysis of various variables [12]. The statistical significance level á=0.05.

\section{Test Indicators}

In order to analyze the gait and insole pressure intensity, this paper selects relevant indicators to carry out measurement and analysis. The main names and descriptions are shown in Table 2 [13].

Table 2: The description of test indicator

\begin{tabular}{cc}
\hline Name & Description \\
\hline Impulse & The pressure-time integral of each partition \\
Average pressure & Average pressure of characteristic area \\
Max pressure & Max pressure of characteristic area \\
Foot axis & The connection of midpoint Heel with the second metatarsal \\
\hline
\end{tabular}

In this paper, the pressure insole area is divided mainly into such three parts as forefoot, midfoot and heel. And great thumb (GT), medial metatarsal (MM), middle metatarsal bones (MidMM), lateral metatarsal (LM) and heel (Heel) were studied mainly.

\section{RESULTS AND DISCUSSION}

\section{Gait Features Analysis}

First, the walking speed, step size, duration, and ground contact area of the test group and 

Table 3.

Table 3: The gait test data

\begin{tabular}{cccccc}
\hline Item & Speed & Step size & Relative step & Lasting time & Contact area \\
\hline 1 & 4.9 & 1.46 & 0.91 & 1.05 & 18.5 \\
2 & 6.9 & 2.01 & 1.25 & 1.04 & 20.0 \\
3 & 5.5 & 1.53 & 0.94 & 1.03 & 17.0 \\
4 & 4.0 & 1.18 & 0.72 & 1.05 & 20.0 \\
5 & 5.7 & 1.70 & 1.01 & 1.06 & 22.5 \\
6 & 4.1 & 1.15 & 0.71 & 0.99 & 21.0 \\
7 & 4.1 & 1.19 & 0.73 & 1.04 & 20.5 \\
8 & 4.4 & 1.45 & 0.89 & 1.08 & 19.0 \\
9 & 5.0 & 1.34 & 0.83 & 1.03 & 20.0 \\
10 & 4.6 & 1.41 & 0.86 & 1.02 & 15.0 \\
\hline
\end{tabular}

Human walking speed is the main characteristic of gait measurement. If the speed significantly slowed down, it indicated that the foot may have pathological signals. When the foot contacts with the ground for a long period, the foot is easy to fatigue and is in a sub-health state. It can be seen from Table 3 that there was no significant difference between the test group and the control group in terms of walking speed, foot contact area and other data [14]. However, the values of walking speed and contact area of the test group were greater than those in the control group, and the contact time with the ground was less than that of the control group, indicating that the testees who have long been engaged in sport dancing training have relatively healthier foot [15]. The strict regulations and requirement on steps, posture, balance and stability, movement and rhythm of sport dancing promote the healthy development of the gait features of the foot.

Table 4 and Table 5 are the test data of the standing duration, effective foot length and stride width of the left foot and right foot in the test group and control group.

Table 4: The test data of left foot

\begin{tabular}{cccc}
\hline & The stand up last time & Foot length & Stride width \\
\hline Test group $(\mathrm{N}=5)$ & $61.00 \pm 1.06$ & $46.12 \pm 17.27$ & $4.92 \pm 0.95$ \\
Control group $(\mathrm{N}=6)$ & $60.08 \pm 0.66$ & $64.75 \pm 8.62$ & $6.05 \pm 1.85$ \\
T value & 1.753 & $-2.333^{*}$ & -1.23 \\
\hline
\end{tabular}

Table 5: The test data of right foot

\begin{tabular}{cccc}
\hline & The stand up last time & Foot length & Stride width \\
\hline Test group $(\mathrm{N}=5)$ & $58.60 \pm 1.08$ & $46.12 \pm 17.27$ & $4.92 \pm 0.95$ \\
Control group $(\mathrm{N}=6)$ & $59.33 \pm 2.56$ & $64.75 \pm 8.62$ & $6.05 \pm 1.85$ \\
T value & -0.593 & $-2.511^{*}$ & -0.304 \\
\hline
\end{tabular}

* signifies that the results have significant differences. $\mathrm{P}<0.05$

It can be seen from the table that there is a significant difference in the effective foot length between the test group and the control group. The decrease in foot length indicates that through sport dancing, the contact area between the foot of students in the test group and the ground has reduced, relative foot length reduced, and the endurance of the bones and muscles of the foot improve somewhat compared with those of the control group [16].

Table 6: Relative standard deviations of the dispersion of insole pressure in a single step of different groups (\%)

\begin{tabular}{cccc}
\hline & Time interval & Left support period & Right support period \\
\hline Test group $(\mathrm{N}=5)$ & $4.44 \pm 2.12$ & $6.48 \pm \pm 2.13$ & $7.90 \pm 3.66$ \\
Control group $(\mathrm{N}=6)$ & $5.03 \pm 2.61$ & $5.57 \pm 2.09$ & $5.50 \pm 4.12$ \\
T value & -0.603 & 0.716 & 1.019 \\
\hline
\end{tabular}


Then, the stability of the foot of the testees was analyzed. The time interval between the two steps was measured and the left and right support period was obtained. And then, the distribution of the insole pressure in a single step of the testee was obtained. Table 6 shows the relative standard deviations of the dispersion of insole pressure in a single step of different groups.

It can be seen from the table that although there was no significant difference between the test group and the control group, the time interval of the test group was shorter than that of the control group, and the supporting time of both the left foot and right foot is longer than that of the control group. The results show that there is less insole pressure dispersion in a single step, and that the foot gait is more stable, which further suggests sport dancing has a positive effect on the improvement of college students' foot gait stability.

\section{Distribution of Insole Pressure Intensity}

\section{Analysis of Maldistribution of the Left and Right Foot Pressure}

From the perspective of biomechanics and motion dynamics, there is a slight difference between the left foot and right foot of humans in terms of structure, toughness, and strength. In the test result, the distribution of the insole pressure intensity of the left and right foot is simulated in the form of 3D image, as shown in Figure 3.

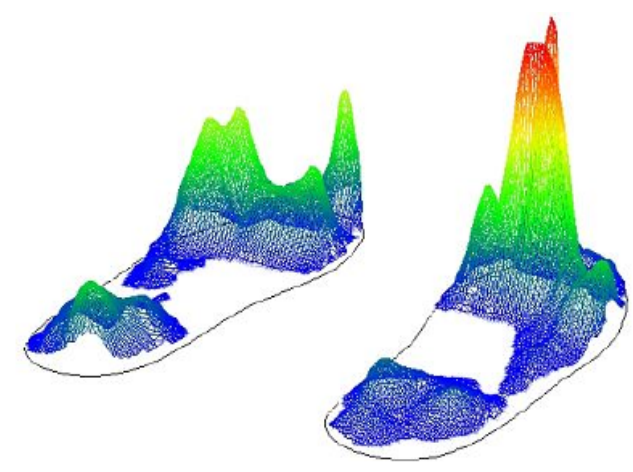

Figure 3. The 3D diagram of insole pressure intensity of the testees' left and right foot in the course of walking

As shown in the picture, the intensity of pressure in the hallux of the right foot is obviously larger than that of the left foot, while the heel of left foot carries larger pressure than the heel of the right foot, suggesting different exercise habits of testees result in differences in the distribution of bipedal pressure. The objective simulation data provided by the foot pressure system is conducive to improving the foot movement habits and can prevent the injuries of skeletons, muscles and joints caused by the continuous uneven pressure distribution.

\section{Plantar Impulse and Foot Gravity Distribution}

The plantar impulse is the buffering ability of all areas of the foot to the acting force between the human bodies and the ground. The integral of the pressure of each area and the time is the impulse. The medial metatarsal area has the largest impulse and the heel has the minimum impulse in the test group. In the control group, the maximum impulse is shown in the heel, and the largest load is in the first and second metatarsal bones.

The foot pressure test system can track the change of the gravity center of the foot of the test group and the control group. The study of the changes in human body gravity is also helpful to evaluate the impact of sport dancing on human foot.

The experimental results indicate that the dispersion degree of the gravity center track of the left and right foot is relatively small in the test group and the connecting lines of the pressure distribution vertical lines of the left and right foot are basically overlapping, while there is little overlap in the gravity center tracks in the control group and the dispersion degree of the tracks is large. The gravity tracks present a brokening trend. The result is that sport dancing is a kind of sport which is very demanding in terms of body balance. For college students in the test group, through the exercise of sport dancing, their physical power can be evenly distributed in the left and right foot, which can better reduce the load bearing and damage to the foot.

\section{Distribution of Average Insole Pressure Intensity}

Next, based on the foot partitions in the experimental design, the distribution of average insole pressure intensity of the college students in the test group and control group was collected. Since the left foot is the main pressure-bearing foot, the statistical data of the left foot are taken. 
Table 7: The mean value of the insole pressure intensity in the test area of the test and control $\operatorname{group}\left(\mathrm{N} / \mathrm{cm}^{2}\right)$

\begin{tabular}{cccccc}
\hline Code & GT & MM & MidMM & LM & Heel \\
\hline $1(L)$ & 7.5 & 12.61 & 4.86 & 3.59 & 5.12 \\
$2(L)$ & 12.1 & 10.34 & 5.12 & 4.86 & 7.21 \\
$3(\mathrm{~L})$ & 4.71 & 8.32 & 6.62 & 4.67 & 4.5 \\
$4(\mathrm{~L})$ & 6.94 & 5.61 & 8.45 & 7.42 & 5.03 \\
5(L) & 5.54 & 7.61 & 5.44 & 7.42 & 5.51 \\
$6(\mathrm{~L})$ & 9.28 & 5.77 & 9.02 & 6.55 & 10.82 \\
$7(\mathrm{~L})$ & 16.09 & 7.11 & 8.76 & 5.19 & 6.71 \\
$8(\mathrm{~L})$ & 10.51 & 6.52 & 8.33 & 4.7 & 8.61 \\
9(L) & 7.25 & 5.6 & 10.80 & 6.61 & 8.71 \\
10(L) & 15.10 & 9.0 & 8.87 & 7.77 & 8.31 \\
\hline
\end{tabular}

It can be seen from the table that the

maximum average pressure of the experimental group is shown in the hallux region, and the
OF COLLEGE STUDENTS

minimum value appears in the heel region. There was a significant difference between the means of pressure in the middle metatarsal region and the hallux region of the left foot $(P<0.05)$.

\section{Distribution of Peak Value of the Insole Pressure Intensity}

Table 8 shows the peak values of the insole pressure intensity of each area of the left and right foot of college students in the test group and control group.

It can be seen from the table that there is significant difference in the the peak values

Table 8: The maximum value of the insole pressure intensity in each region of the left and right foot

\begin{tabular}{|c|c|c|c|c|c|}
\hline Code & GT & $\mathrm{MM}$ & MidMM & LM & Heel \\
\hline Test group $(\mathrm{L})$ & $26.35 \pm D_{-}$ & $35.18 \pm$ & $25.44 \pm D$ & $23.44 \pm D$ & $20.4 \pm \pm \quad D$ \\
\hline Control(L) & $\begin{array}{c}39.35 \pm \pm \\
D_{-}\end{array}$ & $37.18 \pm D_{-}$ & $45.44 \pm$ & $38.44 \pm D$ & $38.4 \pm D$ \\
\hline T value & -1.401 & -0.316 & $-4.191^{*}$ & -1.81 & $-4.979 * *$ \\
\hline Test group(R) & $41.35 \pm$ & $48.18 \pm \mathrm{D}$ & $39.44 \pm$ & $18.44 \pm 9.59$ & $13.4 \pm D$ \\
\hline Control(R) & $41.05 \pm \bar{D}$ & $45.6 \pm D^{-}$ & $38.78 \pm$ & $23.24 \pm D$ & $22.94 \pm \mathrm{DD}$ \\
\hline T value & 0.002 & 0.323 & 0.091 & 0.880 & $-2.556^{* *}$ \\
\hline
\end{tabular}

of the pressure intensity of heel region in the left foot and right foot in the test group and control group. The statistical data show that the maximum pressure intensity is shown in the medial metatarsal and middle metatarsal. They shall be protected specially in daily walking.

\section{Comprehensive Analysis}

Since sport dancing invloves standing, running, jumping and other basic movements in the exercise and competition, the foot is exercised for a long period of time. In addition, sport dancing is demanding for postures and arts, which promotes the steadiness and artistry of the dancer's gait.

Since there are significant differences between the experimental group and the control group in terms of engaging time and technical understanding degree, there are significant differences in the distribution features of pressure and the distribution of pressure. The gravity center distribution of the test group is more uniform and the foot impulse is larger. It is learned from the average pressure intensity value and the average pressure intensity distribution value that there is significant difference in the heel and middle metatarsal areas of the foot of test group and control group, which is related to the fact that the partial areas in the foot bear large pressure for a long time during sport dancing. As the main driving source of foot movement, the pressure intensity distribution in the toe area of the experimental group is greater than that of the control group, so that the body can perform difficult dance movements and maintain the balance of the body.

\section{CONCLUSIONS}

Sport dancing is more and more popular among college students. It is an inevitable trend to scientifically and objectively analyze the influence of sport dancing on the dynamics characteristic of foot movement of college students. In this paper, relevant foot theories were elaborated first, and then the test design process was introduced. The foot pressure test system was adopted to test the data of the test group and the control group and mathematical statistics and analysis were carried out. This paper is instructive in the following aspects:

1. Sport dancing plays an important role in the gait stability of the foot, and plays a positive role in the key parameters affecting gait.

2. There are some differences in 
the pressure intensity data between the experimental group and the control group, and long-term sport dancing had a significant effect on the motion dynamics of the foot movement. On the one hand, sport dancing personnel shall carry out protection to the part bearing large pressure according to relevant test data; on the other hand, the beginners of sport dancing should train the toe area specifically.

3. Sports dancing has a positive effect on the healthy growth of the foot of young college students.

\section{REFERENCES}

1. Liu, X., Research on college sports dance lesson teaching, Lecture Notes in Electrical Engineering, 2013, 225, 239-245, https://doi. org/10.1007/978-3-642-35470-0_29.

2. Hart, M.M., Factors influencing college women's attitudes toward sports and dance, Strength of Materials, 1963, 11, 10, 1173-1176.

3. Rightmire, G.P., Deacon, H.J., Schwartz, J.H., Tattersall, I., Human foot bones from klasies river main site, South Africa, J Hum Evol, 2006, 50, 1, 96.

4. Griffin, N.L., Richmond, B.G., Cross-sectional geometry of the human forefoot, Bone, 2005, 37, 2, 253-260, https://doi.org/10.1016/j. bone.2005.04.019.

5. Boudarham, J., Zory, R., Genet, F., Vigné, G., Bensmail, D., Roche, N. et al., Effects of a knee-ankle-foot orthosis on gait biomechanical characteristics of paretic and non-paretic limbs in hemiplegic patients with genu recurvatum, Clin Biomech, 2013, 28, 1, 73-78, https://doi.org/10.1016/j. clinbiomech.2012.09.007.

6. Burpee, J.L., Lewek, M.D., Biomechanical gait characteristics of naturally occurring unsuccessful foot clearance during swing in individuals with chronic stroke, Clin Biomech, 2015, 30, 10, 1102-1107, https://doi. org/10.1016/j.clinbiomech.2015.08.018.

7. Jonkers, I., Spaepen, A., Weerdt, W.D., Influence of therapeutic bandaging of the hemiplegic foot on gait characteristics of stroke patients, Gait Posture, 1995, 3, 3, 179-180, https://doi. org/10.1016/0966-6362(95)99101-P.

8. Becker, H.P., Rosenbaum, D., Kriese, T., Claes, L., Gait characteristics after malleolar fractures - postoperative pressure distribution beneath the foot in comparison with healthy controls, J Biomech, 1994, 27, 6, 824-824, https://doi.org/10.1016/00219290(94)91395-1.

9. Cynn, H.S., A study of characteristics of foot pressure distribution in trans-tibial amputee subjects, J Biol Chem, 2001, 284, 23, 16004-15.

10. Yu, X., Yu, G.R., Chen, Y.X., Liu, X.C., The characteristics and clinical significance of plantar pressure distribution in patients with diabetic toe deformity: A dynamic plantar pressure analysis, J Int Med Res, 2011, 39, 6, 2352, https://doi. org/10.1177/147323001103900635.

11. Fradet, L., Siegel, J., Dahl, M., Alimusaj, M., Wolf, S.I., Spatial synchronization of an insole pressure distribution system with a 3D motion analysis system for center of pressure measurements, Med Biol Eng Comput, 2009, 47, 1, 85-92, https://doi.org/10.1007/ s11517-008-0382-3.

12. Elliott, A.C., Kwikstat: a low-cost interactive statistical analysis package for ibm-pccompatible computers, Am Stat, 1988, 3, 228-229, https://doi.org/10.2307/2685019.

13. Oliveira, C.S., Camacho, V.T., Estimation of the dynamic characteristics of base-isolated singlespan rc footbridges in portugal based on in situ measurements, Journal of Civil Structural Health Monitoring, 2015, 5, 5, 1-15, https:// doi.org/10.1007/s13349-015-0138-3.

14. Bad'Urová, J., Rosenbaum, D., Nagel, A., The impact of different insole arch supports on the changes of foot loading characteristics, Clin Biomech, 2008, 23, 5, 663-663, https:// doi.org/10.1016/j.clinbiomech.2008.03.003.

15. Powell, D.W., Long, B., Milner, C.E., Zhang, S., Effects of vertical loading on arch characteristics and intersegmental foot motions, J Appl Biomech, 2012, 28, 2, 165173, https://doi.org/10.1123/jab.28.2.165.

16. Witana, C.P., Goonetilleke, R.S., Xiong, S., $\mathrm{Au}$, E.Y.L., Effects of surface characteristics on the plantar shape of feet and subjects' perceived sensations, Appl Ergon, 2009, 40, 2, 267-79, https://doi.org/10.1016/j. apergo.2008.04.014.

(C) 2018 by the author(s). Published by INCDTPICPI, Bucharest, RO. This is an open access article distributed under the terms and conditions of the Creative Commons Attribution license (http:// creativecommons.org/licenses/by/4.0/). 